\title{
HYDROGEOLOGY OF DEEP AQUIFERS The Hydrogeological Basin as the Basis of Groundwater Management
}

by

\author{
Gilbert Castany
}

\begin{abstract}
Recent hydrogeological studies of deep aquifers have demonstrated the importance of leaky flow, the main source of groundwater movement. Carefully coordinated geological, hydrodynamic and hydrochemical research has produced a conceptual model of the aquifer and the hydrogeological basin - useful in establishing a plan for sound development and management of this valuable resource. Deep aquifers represent a water supply source which, if carefully managed, could meet many development needs in arid zones.
\end{abstract}

\section{Introduction}

Deep aquifers are enormous reservoirs of non-renewable potential groundwater resources. They may be supplementary sources of water in humid zones and are commonly the only source of water in deserts. These reservoirs have recently been the focus of heightened interest: some may be sources of geothermal energy, while others are being studied to assess their vulnerability to pollution and leakage from noxious wastes buried deep in the earth. In the past few years, petroleum exploration in sedimentary basins has provided valuable additional information about the nature of deep aquifers.

Effective exploration, development and management of water stored in aquifers of deep basins is the focus of this article. While the volume of water stored in them is large, it must be used wisely, for its renewal through surface infiltration is low or non-existent. Groundwater must be deve-

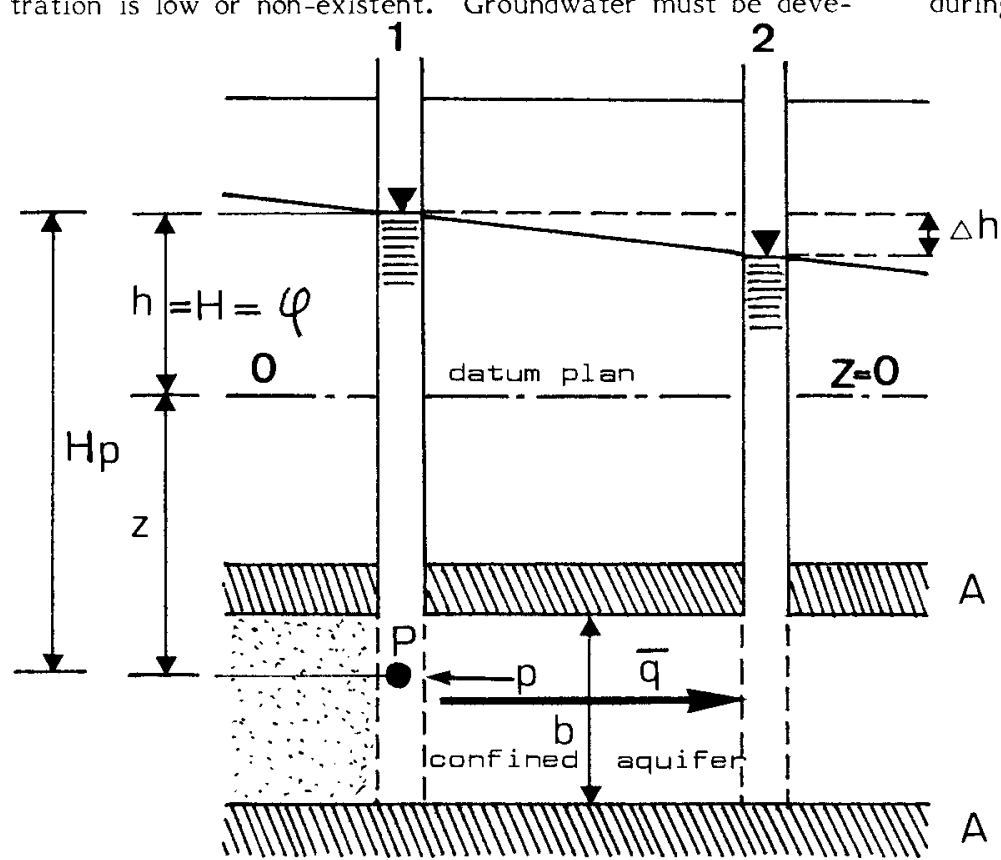

loped as a mineral deposit, and the operation is of ten referred to as "groundwater mining". Technical problems can only be resolved through the use of digital computer hydrodynamic simulation models. The main objective of current hydrogeological studies in such basins, therefore, is the development of a conceptual model to be used as a basis for the modelling.

Basically, the model includes the hydrogeological units and displays the hydrogeological structures which control the spatial distribution of the flow (Figs. $3,5,6,7$ ) to give the flow pattern. The latter consists of flow lines or paths followed by the water particles. Piezometric maps (Fig. 5) are commonly used to show equipotential lines (which are perpendicular to flow lines). The pattern is established through the measurement of the hydraulic potential taken during borings (Fig. 1). The pattern is then refined through

\footnotetext{
piezometric and potentiometric levels on confined aquifer

multilayered aquifer

with ascending leakage

Figure 1. Piezometric and potential levels; multi-layered aquif er and leakage. b: thickness of confined aquifer; h: hydraulic head; H: piezometric level; l: hydraulic potential; Hp: potentiometric level; $\Delta$ h: head or potential difference; $p$ : pore pressure; q: specific flux; $z$ : elevation; A: impervious stratum; B: semipervious stratum (leaky stratum).
}

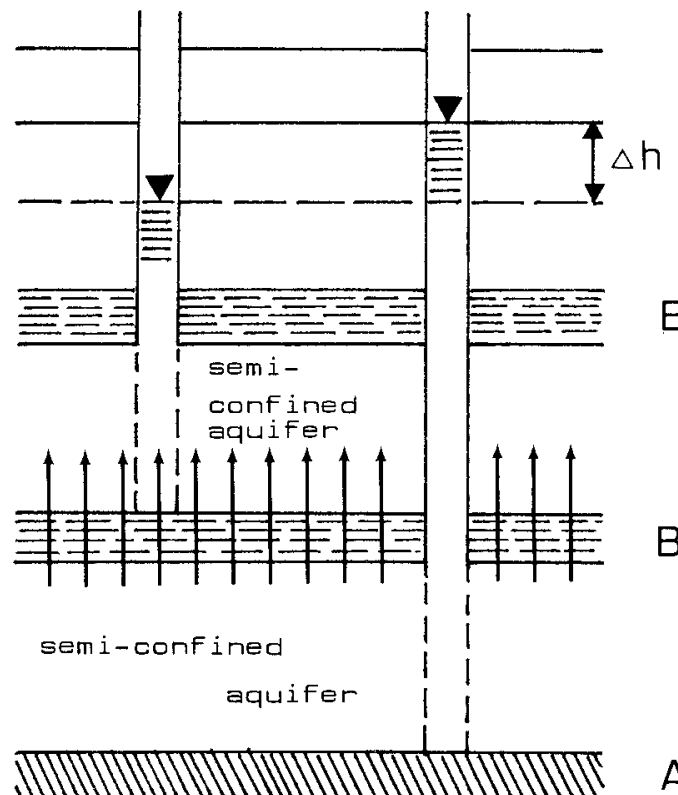

* This article was submitted in French, then translated and edited; copies of the original French text are available, on request, from the EPISODES Secretariat.

EPISODES, Vol. 1981, No. 3. 


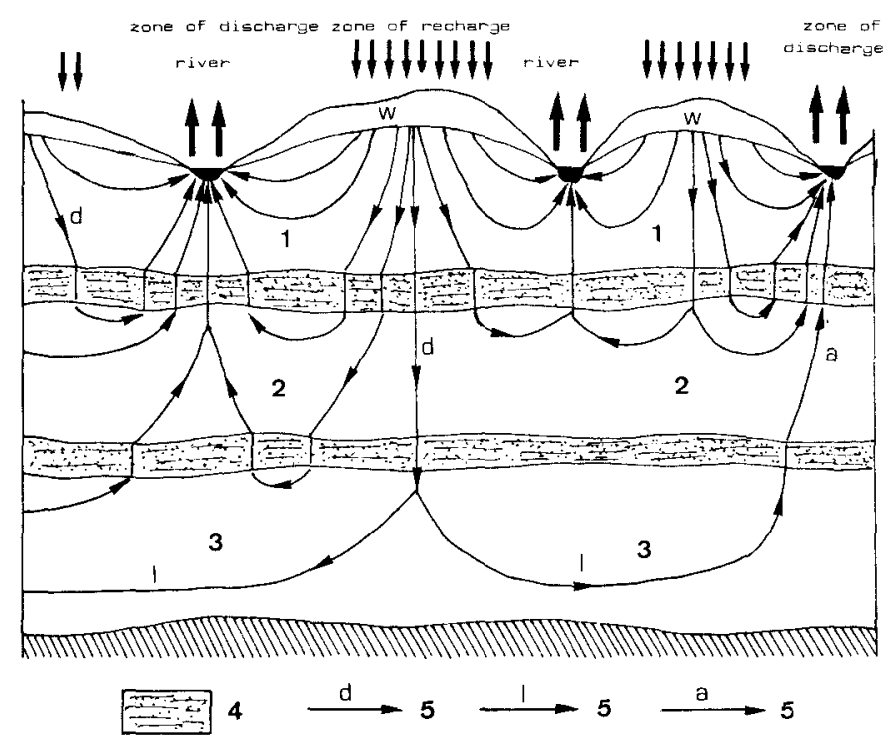

Figure 2. Flow pattern of the multi-layered aquifer (from Llamas and Cruces de Abia, 1978). This section shows the interaction between subsurface aquifers and surface water. I: unconfined aquifer; 2 and 3: leaky aquifers; 4: leaky hydrologic unit; 5: flow system: a - ascending flow, d descending flow, $l$-lateral flow; $w$ : water table.

the use of digital computer models.

\section{Identification of deep aquifers}

The recharge of reserves contained in deep aquifers is characteristically low or barely perceptible. Identification of deep aquifers depends largely on three main disciplines geology, subsurface hydrodynamics and hydrochemistry.

\section{Hydrogeological units and structures}

A hydrogeological unit is a lithostratigraphic unit or reservoir through which water may flow with varying degrees of ease under the impetus of hydraulic gradients or potentials (Castany, 1980). Special attention must be paid to leakage (Hantush and Jacob, 1954), which is the flow of water from one aquifer to the next through an intervening hydrogeological unit of low permeability. A hydrogeological unit composed of alternating layers of pervious and semi-pervious formations is known as a multi-layered aquifer (Figs. 1, 2).

Water moves between aquifers not only by leakage but along stratigraphic and tectonic discontinuities. Thus, for purposes of groundwater management, each sedimentary or hydrogeological basin (Fig. 3) represents a unique hydrodynamic and hydrochemical complex.

\section{Hydraulic potential and leakage}

Measurements in borings are used to calculate the four main hydrodynamic parameters: volume, permeability, hydraulic potential, and leakage, of which only the latter two are discussed here.

Hydraulic potential is the driving force behind the movement of water, determined by two methods (depending on the depth of the aquifer being tested) and calculated in relation to the geographic zero datum level. The methods are:

(i) measurement of the piezometric level or the elevation of the standing water level in the structure, and

(ii) measurement of the reference pressure, the equivalent of which, in metres of water, is the potentiometric level (Chiarelli, 1973).

The spatial distribution of these parameters (Fig. 5) is then displayed on piezometric or potentiometric maps.

Leakage results from two conditions, one of which is geolog-

EPISODES, Vol. 1981, No. 3.

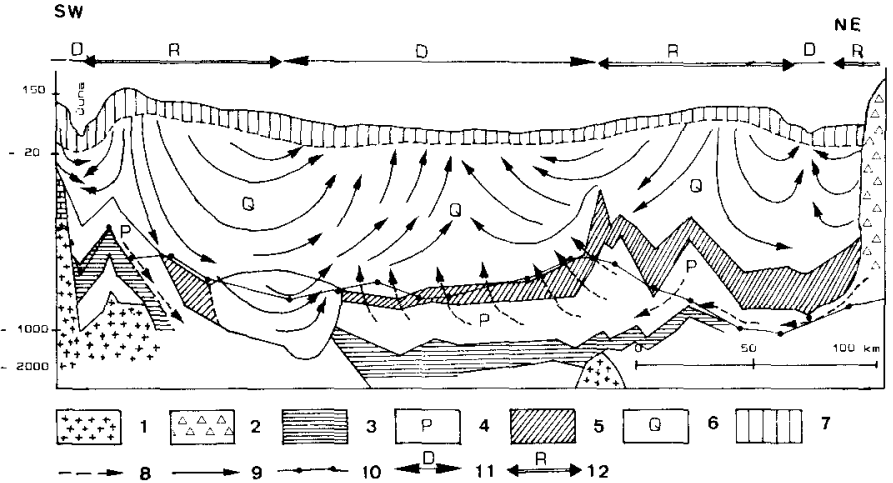

Figure 3. Diagrammatic flow pattern of the Great Hungarian Plain (from Erdelyi, 1978). Basement: 1: Crystalline; 2: Miocene volcanics. Hydrogeologic Units: 3: Lower Pannonian (Pliocene), impervious or poorly pervious hydrologic unit; 4 : Upper Pannonian (Pliocene), pervious hydrologic unit; 5: impervious or poorly pervious hydrogeologic unit of the Pliocene; 6: pervious hydrogeologic unit of the Quaternary. Hydrogeological zones of aquifers: 7: zone of the subsurface aquifers with local flow system; 8: zone of the deep aquifers with large scale flow; 9: zone of the intermediate aquifers with regional flow; 10: fresh and salt-water interface; 11 : discharge area; 12: recharge area.

ical in nature and requires the presence of a semi-pervious hydrogeological unit, while the other is hydrodynamic in nature, produced by the potential gradient between the aquifer in question and those which surround it (Fig. 1). The direction and magnitude of this gradient determine the direction and magnitude of the mixing, whether ascending or descending. Leakage can even increase the productivity of one aquifer at the expense of others as, for example, in the case of the Paris and northern Sahara basins described below. Leakage patterns can be identified using maps of potential difference, which are prepared through the interpretation of piezometric and potentiometric maps.

\section{Hydrochemical parameters}

These are the parameters of the water/rock interactions, the solutions present and the changes which occur in them through space and time. They identify the water types or hydrochemical facies. By observing the changes in these parameters, we can confirm the consistency and adequacy of the hydrodynamic data.

The three main hydrochemical mechanisms are solution, ion exchange and saline filtration or osmosis across the clay/reservoir interface. Environmental isotopes warrant special attention since they provide invaluable information concerning the hydrochemical mechanisms. Oxygen-18 and deuterium are indicative of recharge zones (open systems) and confined zones (closed systems) respectively. In the case of the latter, they make it possible to relate the origin of the water to paleoclimates (paleohydrology). Carbon-14 and tritium reveal the order of magnitude of the "average age" of the subsurface water. Isotopes thus make it possible to reconstruct the chronological events of the recharge, to detect leakage and to identify the major hydrogeological zones, such as in the multi-layered Albian sands aquifer of the Paris basin (Evin and Vuillaume, 1970 and Melloul, 1979), the Upper Senonian sands aquifer in Senegal (Castany et al., 1974), the Nubian sandstone aquifer of the Sinai (Issar et al., 1972; Melloul, 1979), and the "continental intercalaire" 
aquifer of the northern Sahara (Conrad and Fontes, 1970 and 1972).

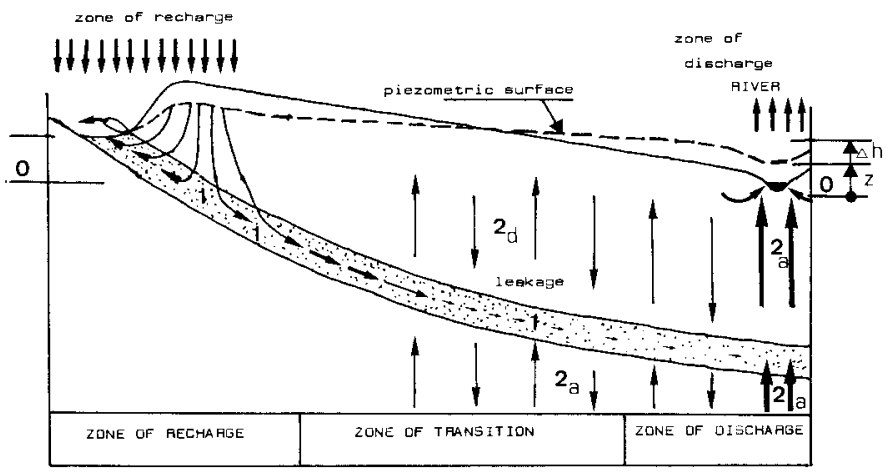

Figure 4. Schematic cross section of a deep aquifer. Lateral flow decreases toward the centre of the basin, where leaky flow predominates.1: lateral flow; 2: leaky flow-2a: ascending, $2 \mathrm{~b}$ : descending.

\section{Major zones in hydrogeological basins}

By acquiring and processing data on the hydrodynamic and hydrochemical parameters, we are able to construct the conceptual model of the hydrogeological basin or the aquifer. Three major hydrogeological zones have been identified and may be classified according to depth (Figs. 2, 3) and distance from the outcrops (Figs. 4,5,6,7). In groundwater flow systems, there are two major types of flow (Fig. 4):

- lateral flow - from intake zones (recharge) to outlet zones (discharge); and

- leaky flow - ascending or descending in a subvertical direction. Compared to lateral flow, leaky flow is usually faster, generally leading to a greater flow.

The lateral flow regime is identified by analyzing the piezometric surface, which makes it possible to locate the intake and outlet zones and the main flow lines as, for example, with the multi-layered Albian sands aquifer of the Paris basin (Fig. 5) and the continental facies aquifer of the northern Sahara (Fig. 7).

Since the phenomenon of leakage is a general one, water loss from a deep aquifer and input from external sources are common. As a result, groundwater discharge increases and

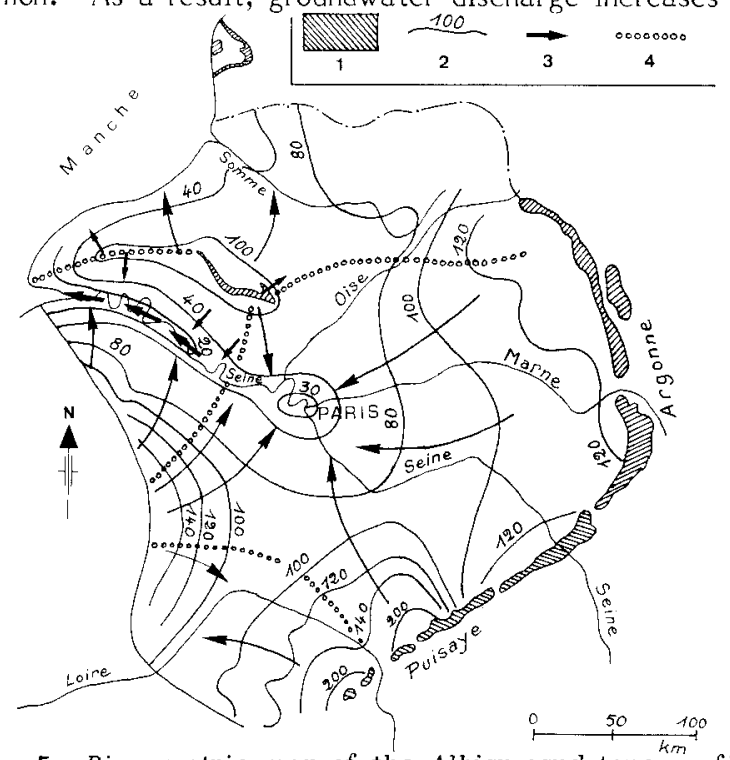

Figure 5. Piezometric map of the Albian sandstone confined aquifer of the hydrogeological basin of Paris and drainage of the river Seine. 1: outcrops; 2: piezometric line with piezometric level; 3: main flow line; 4: groundwater divide.

EPISODES, Vol. 1981, No. 3. diminishes in the direction of the flow (Fig. 4). At the boundary, in the main drainage lines, it can be nil (Margat, 1969). Thus, discharge rates as commonly measured account for only a small fraction of the rate of infiltration through the outcrops, and may even be nil. The traditional concept of balance cannot be used in rational management and must be replaced by the study of boundary conditions.

Vertical zoning in a hydrogeological basin

The two types of flow may be classified under three flow systems - local, regional and global (Fig. 3). A vertical crosssection may reveal three major flow system zones, although this paper concentrates only on the deepest (Fig. 2,3). In descending order, they are:

- Zone of the subsurface aquifers with local flow systems; this zone reaches depths of 50 to $100 \mathrm{~m}$, depending on the hydrogeological structures and surface infiltration;

- Zone of the intermediate aquifers with regional flow systems in confined aquifers; rates of flow are of the order of $10 \mathrm{~m}$ per year. This zone reaches depths of 200 to 300 $\mathrm{m}$, depending upon the hydrogeological structures.

- Zone of deep aquifers with large scale flow systems in which vertical mixing predominates over lateral flow. This zone, therefore, is almost exclusively an area of leaky flow, enhanced by the compaction of clay formations in areas of active orogeny. The rate of flow is very slow - of the order of a metre to $10 \mathrm{~cm}$ per year. The depth of groundwater development for human purposes is limited by the increased mineralization of subsurface water $(1000 \mathrm{~m}$ in the Paris basin, $2000 \mathrm{~m}$ in the northern Sahara basin).

The conceptual models apply only to these three zones - the ones with appreciable flow. Below these levels, in the zone of the very deep aquifers, the flow systems are generally poorly known. The rare exchanges which occur are solely the result of pressure, particularly that which is conducive to the consolidation of sediments. The effect of heat is significant in the very deep layers.

The following table summarizes recently published estimates by Soviet hydrologists of the volume of water stored in aquifers, according to depth.

TABLE 1

Surface Stored water (in millions of $\mathrm{km}^{3}$ ) Volume/ Area Unit Area $\left(\mathrm{km}^{2}\right) \quad 0-100 \mathrm{~m} \quad 100-200 \mathrm{~m} \quad 200-2000 \mathrm{~m}$ Total $\left(\mathrm{km}^{3} / \mathrm{km}^{2}\right)$

\begin{tabular}{lclllll}
\hline Europe & 10.5 & 0.2 & 0.3 & 1.1 & 1.6 & 0.15 \\
Asia & 43.5 & 1.3 & 2.1 & 4.4 & 7.8 & 0.18 \\
Africa & 30.1 & 1 & 1.5 & 3.0 & 5.5 & 0.18 \\
North America & 24.2 & 0.7 & 1.2 & 2.4 & 4.3 & 0.18 \\
South America & 17.8 & 0.3 & 0.9 & 1.8 & 3 & 0.17 \\
Australia & 8.9 & 0.1 & 0.2 & 0.9 & 1.2 & 0.13 \\
\hline Total & 135.0 & 3.6 & 6.2 & 13.6 & 23.4 &
\end{tabular}

Hydrogeological zones of a deep aquifer

Three hydrogeological zones may be identified according to distance from the outcrops. These zones may be characterized by their geological, hydrodynamic and hydrochemical properties, as well as by the isotopes that are present (Melloul, 1979). Two specific cases - one in a humid zone, the other in an arid zone - are described here.

\section{Multi-layered Albian sands aquifer, Paris basin}

This is an example of an aquifer located in a humid zone with intensive urban, industrial and agricultural development. With a surface area of $100000 \mathrm{~km}^{2}$, this aquifer is one of the largest in western Europe. Thorough study of it began over a century ago and has produced a comprehensive body of knowledge summarized in three recent publications (Castany and Megnien, 1974; Lauverjat, 1966; Melloul, 1979).

At the centre of the basin, the depth of the aquifer roof ranges from 500 to $700 \mathrm{~m}$. Data compiled and completed using computer models have identified the following three hydrogeological zones (Figs. 5, 6): 


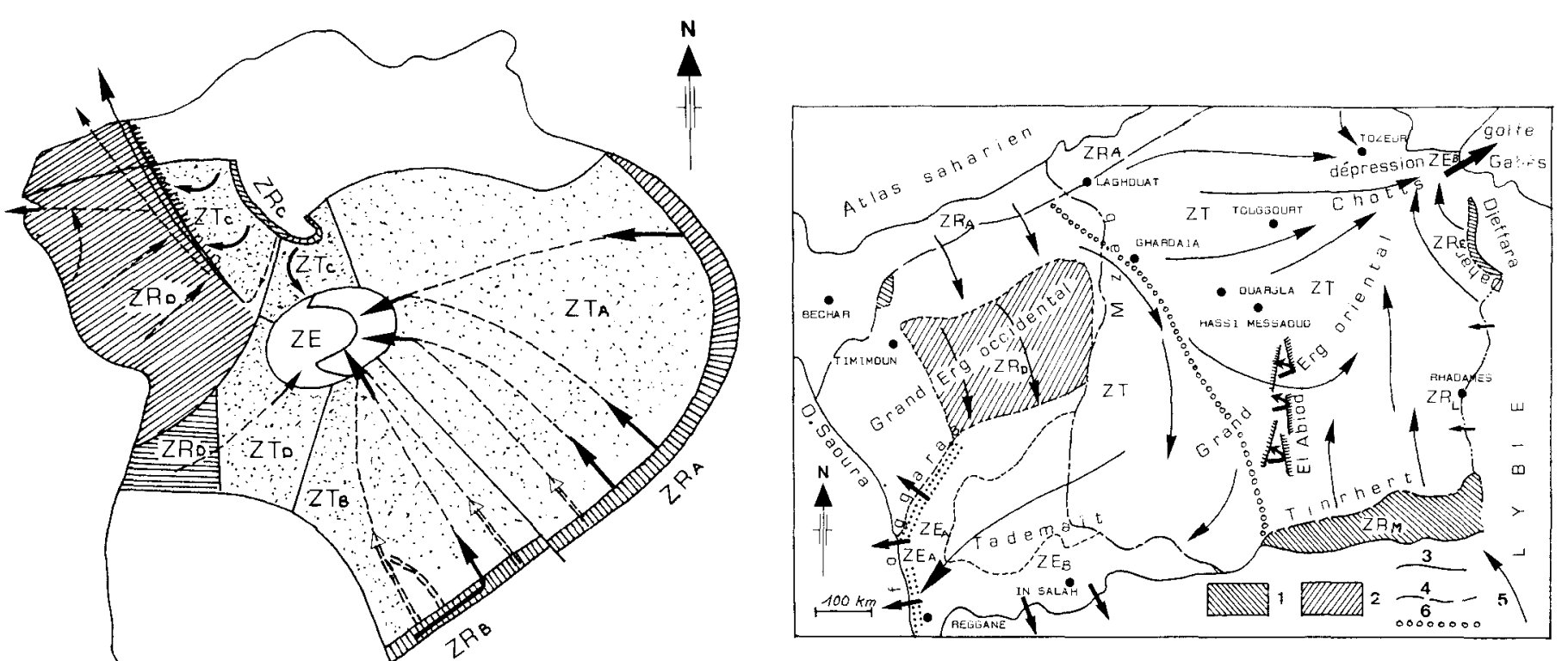

Figure 7. The continental intercalaire aquifer of the northern Sahara; map of subsurface flow (af ter Unesco, 1972). 1: Zone of intake along the outcrops of the aquifer $-Z R_{E}$ : Dahar, $Z R_{I}$ : Lybia, $Z R_{M}$ : Tinrhert, $Z R$ : infiltration in the piedmont area of the Sahara Atlas Mountains. 2: Zone of intake produced by leakage from the unconfined sand aquifer of the Grand Erg Occidental $-Z R$. 3: Boundary of the hydrogeological basin. 4: Maximum western extension of the superposed aquifer of the terminal complex. 5: Flow line. 6: Boundary of the hydrogeological zone.

Figure 6. Hydrogeological model of the Albian sandstone confined aquifer of the Paris basin (from Melloul, 1979). 1: Intake or recharge zones - $Z R$ and $Z R$ : zone of intake along the outcrops of the eastem boundary, $Z R$ : $z$ one of intake along the outcrops of the Pays de Bray $Z R^{\prime}$ : zone of intake produced by descending leakage beneath the Cretaceous cover 2: Transition or mixing zones - $Z T, Z T$ and $Z T_{C}$. 3: Outlet or ascending leakage discharge zone $-Z E$, in the ${ }^{C}$ Paris region developed by boring. 4: zone boundary; 5 : lower Seine fault; 6 : main axes of flow.

Intake or recharge zones, which correspond to the geological boundaries formed by the outcrops of the aquifer, and to the areas of descending leakage, extending them a few tens of kilometres in the direction of the centre of the basin (Fig. 4). In the western sector, there is a major intake zone ( $Z R_{\mathrm{R}}$ ), which is fed by descending leakage through the Cretaceous cover. Lateral flow predominates, converging from the periphery to the centre in the Paris region. Of interest are the local flows along the SE boundary $\left(Z R_{R}\right)$ which move in a SSW-NNE direction, then shift toward the centre and travel NNW-SSE along the edge of the Pays de Bray. These recharge zones may be identified with the vertical zone of the subsurface aquifers (Fig. 4). The carbon-14 content of the water is high, and tritium is often present. The oxygen-18 content of the water is close to that of the surface water which feeds it. Outlet or discharge zones are of two types. The first, a natural outlet zone at the centre on the Ile de France (ZE) was created by intensive boring. During recent decades, a broad piezometric depression, $50 \mathrm{~km}$ in diameter and extending $80 \mathrm{~m}$ along its axis, has appeared in this sector. The second is a shallow natural outlet zone, directly below the lower Seine valley and marked by a piezometric furrow along the river bed (Fig. 5). It reproduces, below the surface, the pattern of the major drainage axis created by the watercourse along the piezometric surface of the subsurface aquifers. The potential differences created in this way produce an active ascending leaky flow (Fig. 4). Carbon-14 levels are either low or non-existent.

Transition or mixing zones (ZT) mark the gradual change from intake zones to outlet zones. Lateral flow gradually decreases and is very weak in the outlet zones. Leaky flow increases and produces ascending (rarely descending) vertical exchange (Fig. 4).

The rate of recharge of renewable potential groundwater resources through the intake of water into recharge zones is slow (22 million $\mathrm{m}^{3} /$ year), particularly in comparison with the total reserve of 425 billion cubic metres of non-renewable EPISODES, Vol. 1981, No. 3.

groundwater resources. The increase in the number of borings between 1841 and 1935, with a rate of withdrawal of 34 million $\mathrm{m}^{3} /$ year, has produced the piezometric depression observed on the Ile de France - a fact that demonstrates the great sensitivity of deep aquifers to development and the need for careful planning. The rate of withdrawal was reduced to 16.5 million $\mathrm{m}^{3}$ /year in 1977 .

Because of the existence of other potential sources of supply (purification of surface water and of subsurface water to a depth of $150 \mathrm{~km}$ ), a transient flow computer model was developed to plan the utilization of the aquifer at a rate of 18 million $\mathrm{m}^{3} /$ year $\left(0.57 \mathrm{~m}^{3} / \mathrm{s}\right)$. This plan provides reserves as a backup supply to be used in the event of the accidental pollution of surface water, or as a means of compensating for a shortage during a year of low rainfall. The rate at which the water is withdrawn is adjusted over time and may, for example, amount to $2 \mathrm{~m}^{3} / \mathrm{s}$ over three months, or $7 \mathrm{~m}^{3} / \mathrm{s}$ over one month, with the balance being restored during interruptions in flow. Artificial recharging of aquifers has also been attempted with success.

\section{Continental intercalaire aquifer, northern Sahara}

This aquifer - a reservoir of Lower Cretaceous continental sand deposits with local Jurassic deposits at its base - is part of the large hydrogeological basin of northern Sahara. It is an example of an aquifer located in an arid zone. It covers an area of $600000 \mathrm{~km}^{2}$ in southern Algeria and Tunisia, and has been well studied and reported on. The depth of the aquifer roof reaches $1000 \mathrm{~m}$ in the west, $500 \mathrm{~m}$ at its centre and in places extends to $2000 \mathrm{~m}$.

The data compiled describe two major flow systems which correspond to the intake and outlet zones (Fig. 7). By adjusting the computer models to a permanent regime, it has been possible to verify the consistency of the data and specify or calculate the rate of inflow and outflow across the boundaries of the aquifer.

The Grand Erg Occidental - Tademait hydrogeological zone in the west consists of two intake zones: one, to the NW $\left(Z R_{A}\right)$, is an infiltration surface for runoff from the piedmont area of the Sahara Atlas Mountains $\left(2 \mathrm{~m}^{3} / \mathrm{s}\right)$; the other is at the centre $\left(Z R_{0}\right)$, where descending leakage occurs from the unconfined sand aquifer of the Grand Erg Occidental (3.55 $\mathrm{m}^{3} / \mathrm{s}$ ). The NS and NNE-SSW axes of flow in the central transition zone indicate draining toward the outlets at the 
western $\left(Z E_{A}, 1.8 \mathrm{~m}^{3} / \mathrm{s}\right)$ and southern $\left(Z E_{B}, 1.94 \mathrm{~m}^{3} / \mathrm{s}\right)$ boundaries from the outcrops of the aquifer of the Tademait plateau.

The Grand Erg Oriental - Tinrhert-Chotts hydrogeological zone in the east consists of the major outlet zone of the closed depression - a vast basin of evapo-transpiration formed by the great shotts (shallow and brackish or saline lakes or marshes) of southern Algeria and Tunisia (leakage and springs: $0.3 \mathrm{~m}^{3} / \mathrm{s}$ ). However, the main outlet for the entire aquifer is provided by the underground flow into the Gulf of Gabès $\left(3.6 \mathrm{~m}^{3} / \mathrm{s}\right)$. The intake zones are: the Tinrhert outcrops to the south $\left(Z_{M}, 0.43 \mathrm{~m}^{3} / \mathrm{s}\right)$, the Dahar outcrops to the NE $\left(Z R_{E}, 2 \mathrm{~m}^{3} / \mathrm{s}\right)$, and to the east, the lateral flow from the Lybian aquifer $\left(A_{L}, 0.5 \mathrm{~m}^{3} / \mathrm{s}\right.$ ). For the transition zone, the major axes of flow lie in an EW direction in the shotts basin to the north, and in a NS direction to the south. In the centre, the El Abiod submeridan faults allow leakage to occur through the roof of the formation at an estimated rate of $0.55 \mathrm{~m}^{3} / \mathrm{s}$.

The groundwater resources are recharged at the rate of 8.5 $\mathrm{m}^{3} / \mathrm{s}$ ( 270 million $\mathrm{m}^{3} /$ year $)$, a significant proportion of which is contributed by leaky flow $\left(3.55 \mathrm{~m}^{3} / \mathrm{s}\right)$. The volume of these is low if compared to the $60000 \mathrm{~km}^{3}$ of non-renewable groundwater. In 1956, intake and outlet rates for the aquifer were balanced with the outflow of $0.32 \mathrm{~m}^{3} / \mathrm{s}$ through kanats and borings. Their increase to $3 \mathrm{~m}^{3} / \mathrm{s}$ in 1970 resulted in a draw on the reserve of $2.57 \mathrm{~m}^{3} / \mathrm{s}$ in 1970 , or $154 \mathrm{~m}^{3}$ over the period from 1956 and 1970 . This produced a lowering of the piezometric surface in the affected zones, followed by a decrease in the flow from springs and artesian wells in southern Algeria and Tunisia. As in the case of the Paris basin, one concludes, therefore, that deep aquifers are very sensitive to development.

A groundwater development plan for agricultural purposes was prepared using transient regime computer models, and two strategies were proposed. The first, a modest and more realistic plan, would increase the area under irrigation in Algeria to 56890 hectares from the present 29890 , and in Tunisia to 23000 from the present 15 520; the second, a more ambitious plan, would lead to the development of 74890 hectares in Algeria and 27610 hectares in Tunisia.

\section{Planning and development}

Deep aquifers are characterized by high volumes of nonrenewable potential groundwater resources. Equal in volume to existing reserves, they are of the order of hundreds of billions of cubic metres, as indicated by the recent estimates summarized in Table 1. In contrast, the volume which can be obtained by recharging renewable potential groundwater resources amounts to only hundreds of millions of $\mathrm{m}^{3} /$ year. It is for this reason that they are highly sensitive to development by boring - a fact confirmed through studies of specific cases.

Over-development may produce a drop in piezometric levels, which in turn leads to the drying up of wells and artesian springs. Thus, over the medium term, it may be necessary to resort to pumping while attempting to restore levels. The use of these resources is, however, unavoidable, particularly in arid zones where they are of ten the only source of supply. The problems still to be overcome are financial in nature, since the technology is generally equal to the task.

Where development is planned very carefully, it is possible to anticipate long-term needs and to limit the economic and environmental consequences. Such planning can be assisted by digital computer hydrodynamic simulation models which have been tested in many specific cases, notably in the northern Sahara hydrogeological basin. Based on what we have seen in the past, the medium and long-term forecast for several decades to come is that deep aquifers will constitute a realistic and dependable source of water supply, and that energy will represent the bulk of the water-production costs.

\section{References}

Albinet, M. and Cottez, S., 1967, Utilisation et interprétation des cartes de différences de pressions entre nappes superposées: Chron. Hydrogéologie, BRGM - Orléans, 12, p.43 48.

Astie, H., Bellegarde, R. and Bourgeois, M., 1967, Contribution à l'étude des différences piézomètriques entre plusieurs aquiferes superposes. Application aux nappes du Tertiaire de Gironde: Chron. Hydrogéologie, BRGM Orléans, 12, p.49-59.

Bogomolov, Y.G., Kudelsky, A.V. and Lapshin, N.N., 1978, Hydrogeology of large sedimentary basins. Hydrogéologie des grands bassins sédimentaires: LAH Mém. XI, Budapest, p. $117-122$.

Castany, G. and Megnien, C. (eds.), 1974, Les bassins de la Seine et des cours d'eau normands. Tome I: Ressources deau et données hydrologiques, fasc. 4, eaux souterraines: Mission Deleguée de Bassin Seine-Normandie, Paris, $157 \mathrm{p}$.

Castany, G., Marce, A., Margat, J., Moussu, H. and Vuillaume, Y., 1974, Etude par les isotopes du milieu du régime des eaux souterraines dans les aquifères de grandes dimensions, Isotope techniques in groundwater hydrology: Proc. IAEA Ser. 1, Vienna, p.243-258.

Castany, G., 1980, Faire connaissance avec l'eau propre: Hachette, Paris, 200p.

Cazal, A., Plaud, M., Pouchan, P. and Vouve, J., 1969, Esquisse hydrogéologique des nappes profondes de l'Aquitaine orientale: Mém. BRGM No. 76, Orléans, p.795-802.

Chiarélli, A., 1973, Etude des nappes aquifères profondes. Contribution de l'hydrogéologie à la connaissance d'un bassin sédimentaire et à l'exploration pétrolière: Thesis Univer. Bordeaux, I. ELF-ERAP, Paris.

Chiarélli, A., 1978, Etude des nappes aquifères profondes du bassin de Douala (Cameron). Hydrogéologie des grands bassins sédimentaires: IAH Mém. XI, Budapest, p.322-335.

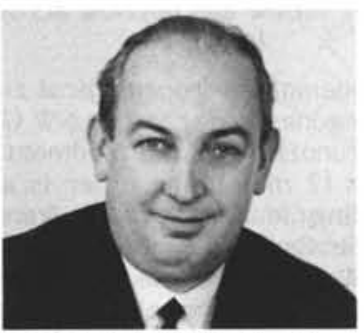

EPISODES, Vol. 1981, No. 3.
Conrad, G. and Fontes, J.C., 1970, Hydrologie isotopique du Sahara nord-occidental, in Isotope hydrology: Proc. IAEA Ser. I, Vienna, p.405-419.

Conrad, G. and Fontes, J.C., 1972, Circulations, aires et périodes de recharge dans les nappes aquifères du NordOuest saharien; données isotopiques: Acad. Sci. C.R., Paris, Ser. D, 275, No. 2, p.165-168.

Erdelyi, M., 1978, Hydrodynamic of the Hungaria basin. Hydrogéologie des grands bassins sédimentaires: IAH Hydrogéologie des grands bassir
Mém. XI, Budapest, p.146-161.

Evin, J. and Vuillaume, Y., 1970, Etude par le radiocarbone de la nappe captive de l'Albien du bassin de Paris, in Isotope hydrology: Proc. IAEA Proc. Ser. I, Vienna, p.315. 332.

Freeze, R.A. and Witherspoon, P.A., 1966, Theoretical analysis of regional groundwater flow. 1: Analytical and numerical solutions to the mathematical model: Water Resour. Res., 2, No. 4, p.641-656.

Freeze, R.A., 1971, Three-dimensional, transient, saturatedunsaturated flow in a groundwater basin: Water Resour. unsaturated flow in a gr
Res., 7, No. 2, p. $347-366$.

Habermehl, M.A., 1980, The Great Artesian Basin, Australia: B.M.R. Journ. of Australian geol. and geoph., 5, p.9-38.

Hantush, M.S. and Jacob, C.E., 1954, Plane potential flow of groundwater with linear leakage: Eos Trans. AGU, 35, No. 6, p.917-936.

Hubbert, K., 1969, The theory of groundwater motion and related papers: Hafner Publishing Company, New York and London, 310p.

Issar, A., Bein A., and Michaeli, A., 1972, On the ancient water of the upper Nubian sandstone aquifer in central Sinai and southern Israel: ]. Hydrol., 17, No. 4, p. 353-374.

Kiraly, L, 1970, L'influence de l'hétérogénéité et de l'anisotropie de la perméabilité sur les systèmes d'écoulement: Bull. Ver. Schweiz. Pet.-Geol. Ing., 37, No. 91, p.50-57.
Kovacs, G., 1978, Rapport general: Hydrogeologie des grands bassins sédimentaires: IAH Mém. XI, Budapest, p.35-55.

Lauverjat, J., 1966, Contribution à l'étude géologique et hydrogéologique de l'Albien dans le centre du bassin de Paris: Univ. Par is Vl, thèse 3éme cycle.

Llamas, M.R. and Cruces de Abia, J., 1978, Conceptual and digital models of the groundwater flow in the Tertiary basin of the Tagus River (Spain): IAH Mém. XI, Budapest, p.186-202.

Margat, J., 1969, Remarques sur la signification des surfaces piezometriques des nappes captives: Chron. Hydrogéol, BRGM Orléans, 12, p.13-17.

Megnien, C., 1979, Hydrogéologie du centre du bassin de Paris: Mém. BRGM, Orleans, 98, 532p.

Melloul, A., 1979, Contribution à la connaissance hydrogéologique des grands aquifères profonds en milieu poreux à données peu nombreuses: Bull. Cent. Hydrogéol., Neuchatel, No. 3, p.55-94.

Reboucas, A., de Cunha, 1978, Le grand bassin hydrogéologique du Maranhao, Brésil. Perspectives de l'exploitation. Hydrogéologie des grands bassins sédimentaires: IAH Mém. XI, Budapest, p.448-461.

Toth, J., 1962, A theory of groundwater motion in small Irainage basins in central Alberta, Canada: Jour. Geophys. Res., 67 , No. 11 , p.4375-4387.

Toth, J., 1978, Gravity-induced cross-formational flow of formation fluids, Red earth region, Alberta, Canada: analysis, patterns and evolution: Water Resour. Res., 14, No. 5, p.805-843.

Unesco, 1972, Etude des ressources en eau du Sahara septentrional: Unesco publ., Paris.

Unesco, 1978, World water balance and water resources of the Earth. U.S.S.R. Comm, for the intern, hydro, decade: studies and reports in hydrology, No. 25 , Paris.

ABOUT THE AUTHOR: Dr. Gilbert Castany, a specialist in the hydrogeology of arid and semiarid zones, is particularly interested in the exploration, evaluation, and development of groundwater resources. Currently President of the International Association of Hydrogeologists (IAH) - an affiliate of IUGS, Dr. Castany is a professor at both the Universite de Paris VI and Montpellier University, as well as at the Ecole national du Génie rural; he serves as a consultant to Unesco on hydrogeology. 